\title{
Max U versus Humanomics: a critique of neo-institutionalism
}

\author{
DEIRDRE NANSEN MCCLOSKEY* \\ Departments of Economics, History, English, and Communication, University of Illinois at Chicago, Chicago, IL USA
}

\begin{abstract}
Institutions' do not mean the same thing to Samuelsonian economists as they mean to other people. North's 'rules of game', like chess, dominates, even when it is claimed that 'informal institutions' are allowed into the tale. The tale is that institutions were once clotted, and then became unclotted, and the Great Enrichment occurred. But the enrichment was by a factor of upwards of a hundred, which cannot be explained by routine movements to an efficient equilibrium. And changes of institutions did not in fact happen much in England. Ethics changed, not laws and procedures. For presently poor countries, too, it will not suffice, as the World Bank and Acemoglu recommend, to add institutions and stir. Economies rely on ethics, which neo-institutionalists, being at heart Samuelsonian, have not wanted to admit. Ideas matter. Indeed, metaphors and stories matter, as in Searle's account.
\end{abstract}

Like the old Marxists, and the older Christians, the neo-institutionalists among Samuelsonian economists want a theory that would, if it were true, have allowed them in 1700 to lay down the future. ${ }^{1}$ They want the story of the Great Enrichment - the utterly strange magnitude of which they of course acknowledge, being competent economists and economic historians - to be a story of what they call 'institutions'.

Yet by 'institutions' the economists do not mean what other social scientists mean by institutions, such as marriage or the market - which is to say the good or bad dance of human lives, full of human meanings and improvisations. As May West said, 'I admire the institution of marriage. But I'm not ready for an institution'. Norms are ethical persuasions, bendable, arguable, and interpretable. Rules are, well, rules, such as that bribes are illegal in India, or that jaywalking is illegal in downtown Evanston. The rules of bribery in Sweden are probably the same as in India, and the jaywalking rules

\footnotetext{
*Email: deirdre2@uic.edu

1 'Samuelsonian' is historically more accurate than the conventional 'neoclassical'. It is the conviction that economics must be about individuals maximizing subject to constraints, what I call below ' $P$-logic'. 'Neoclassical', by contrast, properly includes economists also descended from the revolution of the 1870s, such as Marshallians and Austrians and even Post-Keynesians (though they are more properly to be viewed as classical than neoclassical), all of whom do not think much of what the excellent P. A. Samuelson laid down in his modestly entitled Ph.D. dissertation in 1947 as correct method.
} 
in Germany are the same as in Evanston. The difference is ethics. The English novelist and essayist Parks, who has taught at university in Italy since 1981, notes that it is extraordinary how regularly Italy creates ... areas of uncertainty: How is the law [of, say, train travel with a valid ticket] to be applied?' The 'culture of ambiguous rules' seems, 'to serve the purpose of drawing you into a mindset of vendetta and resentment. ... You become a member of [Italian] society insofar as you feel hard done by, .... [playing in] a gaudy theatre of mimed tribal conflict'. He gives the example of il furbo, the crafty one, who jumps the queue to buy a ticket at the train station, in a way that would get him assaulted by grandmothers in Germany and by handgun licensees in the United States. The law-abiding Italians groan, but do not act effectively to protect the public good of queues. They would rather be resentful, and therefore be justified in taking advantage sometime of their own acts of furbismo. ${ }^{2}$

Economists call ethics often by another name, 'enforcement'. The new word, with its whiff of third-party intervention somehow made legitimate, however, does not make it any less about the ethical convictions with which a group operates. 'Norms' are one thing, 'rules' are another. The neo-institutionalists turn their arguments into tautologies by melding the two. They end up saying, 'Social change depends on society'. One supposes so. 'Informal constraints' are not informal if they are constraints, and if they are informal the theory has been reduced to a tautology, because any human action is now by definition brought under the label 'institutions'. The neo-institutionalists have nothing non-tautological to say about ethics, because they have not read the immense literature on ethics since $2000 \mathrm{BCE}$, including the literature of the humanities turning back to look at the rhetoric of language. Being economist, raised on the childish philosophy that separates positive and normative when most of our scientific lives are spent in their intersection, they are quite unwilling to bring ethics seriously into their history and their economics. As one of them said genially to me, 'ethics, schmethics'.

The historian of the medieval English economy Davis concludes on the contrary that 'without a proper understanding of the morality and social conventions of the marketplace, the historian cannot understand the influence of formal institutions', such as the assize of bread or the rules of guilds. 'In medieval England', Davis writes, a 'pragmatic moral economy ... was not a simple, efficient alignment of institutions and cultural beliefs, but rather a heady and complex mixture of vested interests, pragmatism and idealism that varied according to the prevailing circumstances', ranging from the pressures of the market to the preachments of the pulpit. ${ }^{3}$ One reason that bankers in Florence financed the explosion of sacred art and architecture in the quattrocento is that

2 Parks (2013), pp. 8-9, 18, 143-144.

3 Davis (2012), pp. 453-455. 
the preachers were telling them they would go to hell for the sin of usury, and had only one chance to prevent it. The political economists Rossi and Spagano have argued plausibly that evolved custom can work pretty well in contexts without the printing press, but that black-letter law gives all parties public knowledge, and leads to efficiencies. ${ }^{4}$ The argument is surely correct. And yet, as Rossi and Spagano would perhaps concede, it leaves a gigantic area in an economy for custom or ethics or play, not write-down-able. And indeed black letters never come with their own interpretation, a point that for example the literary critic and public intellectual Fish makes about legal documents and Milton's poetry. He points out that interpretive communities give the meaning of a law or a poem. ${ }^{5}$ And those communities can be called ethical (which includes bad as well as good customs). Yes, sometimes writing down the customs/ethics is a clarifying improvement, in just the way Rossi and Spagano propose. A parallel point is the old and conservative one arguing for the educational function of written law. Yet Fish's point remains. Law is a conversation.

Or, I say, a dance. The economists want to narrow the word 'institution' to fit their conception that a dance can be reduced to formulaic steps, maximization under constraints, rigid rules of the game known to all, the constraints being the institutions. That is, economists want formulaic, public incentives to be the main story. One, two, three: ball change, brush, brush, side essence, riffle. True, parts of routines by Bill Robinson or Fred Astaire can be described after the fact in such a formula. But without Robinson or Astaire it's rubbish. It don't mean a thing if it ain't got that swing.

What is deeply superficial, so to speak, about the neo-institutional notion of 'rules of the game' - that is, constraints - is that in the actual economy what - is-to-be-done is continuously under discussion, yet the neo-institutionalists ignore the discussion. People in the Hood, for example, hold that you should not talk to coppers. The police devote great effort, some of it rhetorical, to changing the institution of not being a snitch, not cooperating with The Man, not getting involved in someone else's business. The Broken Windows tactic recommended by Kelling and Wilson (1982). Wilson, for example, is often held up as an example of incentives and constraints. No it isn't. It's an example of trying to change the conversation, changing what people say to themselves when contemplating mugging the woman walking down the street: 'Hmm. This place is pretty fancy. Must be heavily patrolled' or 'Gosh'. Things are so nice around here. I better do what Mom said and be nice'. As Kelling and Wilson (1982) put it, 'vandalism can occur anywhere once communal barriers - the sense of mutual regard and the obligations of civility - are lowered by actions that seem to signal that "no one cares"'.

4 Rossi and Spagano (2014).

5 Fish (1980), throughout, and Fish (2001), again throughout, for example pp. 47, 57, 92. 
It's hard to get through to economists on the point, so enamored are they of the Max-U story of budget lines and incentives, which they have learned since boyhood (I choose the gender carefully) is a complete theory of choice. They have not read with understanding the opening pages of Aristotle's Nichomachean Ethics, for example, or the Exodus of the Jews, or the Mahabharata of the Hindus, all of which exhibit choice as a painful exercise in identity, as against the snappy determinism of a so-called consumer facing so-called budget lines. At a conference in 2010 praising North's contributions, Mokyr wrote: 'institutions are essentially incentives and constraints [there it is: institutions as budget lines] that society puts up on individual behavior. Institutions are in a way much like prices in a competitive market [what did I tell you?]: individuals can respond to them differently, but they must take the parametrically and cannot change them' ${ }^{6}$ Neat. He then in a footnote instructs me on price theory. I get the price theory: price and property, the variables of prudence, price, profit, the Profane as I have called them, move people. ${ }^{7}$ But the point here is that they are also moved by the $S$ variables of speech, stories, shame, the Sacred, and by the use of the monopoly of violence by the state, the legal rules of the game, and the dance in the courts of law, the $L$ variables. Most behavior, $B$, is explained by $P, S$, and $L$, together:

$$
B=\alpha+\beta P+\gamma S+\delta L+\varepsilon .
$$

The equation is not wishy-washy or unprincipled or unscientific. The $S$ and $L$ variables are the conditions under which the $P$ variables work, and the $P$ variables modify the effects of the $S$ and $L$ variables. Of course. For example, the conservative argument that laws serve as education would connect $L$ causally to $S$, by a separate equation. Or again, when the price the Hudson Bay Company offered Indians in Canada for beaver pelts was high enough, the beaver population was depleted, in line with $P$-logic. But $S$-logic was crucial, too, making the $P$-logic relevant. As Carlos and Lewis (1999) explain, 'Indian custom regarding the right to hunt for food and other aspects of their 'Good Samaritan' principle mitigated against the emergence of strong trespass laws and property rights in fur-bearing animals; conflict in the areas around the Hudson Bay hinterland contributed to an environment that was not conducive to secure tenure, and attitudes towards generosity and even a belief in reincarnation may have played a role' in running against better $P$-logic rules that would have preserved the beaver stock. ${ }^{8}$ The institutionalist Adams speaks of the market as an 'instituted process', which is correct. ${ }^{9}$ The institution is the $S$, the process the $P$, and the legal limits $L$. Or sometimes the other ways around. Anyway, often, all.

6 Mokyr (2010), p. 1.

7 McCloskey (1998, 2008). And while we're speaking of price theory, (McCloskey, 1985), available at deirdremccloskey.org.

8 Carlos and Lewis (1999), p. 726.

9 Adams (1994). 
You can get as technical as you want about it. For example, econometrically speaking, if the $P, S$, and $L$ variables are not orthogonal, which is to say if they are not entirely independent, or alternatively if there is reason to believe that a combined variable such as $P S$ has its own influence, then an estimate of the coefficients that ignore $S$ (or $P S$ or $P L$ ) will give biased results. The bias is important if the $S$ variables are important. If laws adjust to markets, to give another example, then $L$ is affected by $P$, and an attribution of an exogenous effect of $L$ would be biased - as it has been, often.

A story goes with it. Once upon a time, the neo-institutionalists claim, Europe did not face the 'right' incentives. Property rights, it is said, were by comparison with modern times imperfect. There is, to be sure, little evidence for such an assertion. Land and husbands and eternal salvation were eagerly bought and sold in the European middle ages, and other, non-European societies often had better, not worse, property rights than Europe did. But for the sake of charitable scientific discussion, set aside that factual problem.

Then in the neo-institutionalist story the incentives righted themselves, and the result was a very large increase of real income per person. There is also little evidence of such a consequence of righted incentives, since often the incentives were already in place. Hardin (1968), for example, made famous a 'tragedy of commons' - in aid, it should be remembered, of a policy of compulsory sterilization of women in poor countries - by ignoring the easily available evidence that medieval people recognized the problem and solved it on the spot with stinting of grazing rights. But in charity again, set aside that factual problem.

Yet a third factual problem remains, which cannot even in charity be set aside. It is that the righting of incentives cannot possibly explain what it sets out to explain, the Great Enrichment and the modern world. Not so long ago a country like Britain or Japan was \$3-a-day poor. Real income per person has by now increased to roughly $\$ 100$ a day. ${ }^{10}$ That is, even when measured conventionally the increase of income per head in real terms since 1800 has been on the order of a factor of 20 or 30 . Allowing for radical improvements in the quality or cost of most goods (lamps, writing instruments) and some services (medicine, travel), not well captured in conventional price indices, it has been upwards of a factor of $100 .{ }^{11}$ These are not controversial figures, not in their orders of magnitude. What economists chiefly need to do - and the neo-institutionalists claim to do is to explain such a Great Enrichment, at a factor since 1800 in real terms per person of 20,30, 100.

10 Maddison (2007).

11 The factor of 100 is argued in McCloskey (2010), pp. 54-59, using Nordhaus on lighting and his suggested extrapolations (Nordhaus, 1996). Fouquet and Pearson (2011) confirm Nordhaus on lighting. 
An economist's tale of increased efficiency can't do it. For one thing, if the slight improvements of incentives that are imagined were so efficacious, they would have been so on the many other occasions in which societies improved a bit, doubling per person real income, say, such as Song China or Imperial Rome. For another, if mere incentives were all that stood in the way of correct allocation, then a reallocation paying off routinely, predictably, with given tastes and technologies, in Samuelsonian fashion - no Schumpeter or Hayek about it - 100 to 1 would presumably have happened, and even would have consciously occurred to someone, in the previous millennia, sometime, somewhere. It would have been a $\$ 100$ bill lying on the floor of a \$1-or-\$3-or-\$ 6-a-day society. The unique magnitude of the Great Enrichment, that is, tells against the economist's reliance on routine incentives. Surely what had to be the cause was something highly peculiar (for a while) to northwestern Europe, not a reallocation of the old things prevalent in most civilizations such as private property, rule of law, literacy, cheap exchange, and predictable investment.

Postulate in charity once more, though, the partial failure of incentives - as neo-institutional theories based solely on a $P$-logic do. It is, I repeat, high charity to do so: virtues other than prudence matter, too. Ideology, rhetoric, a public sphere, public opinion, mattered greatly. As the Christian economist Zamagni puts it, 'Modern economic development did not occur due to the adoption of stronger incentives or better institutional arrangements, but mainly because of the creation of a new culture'. ${ }^{12}$ Or as the Indian businessman and public intellectual Das puts it, 'Social scientists [under the influence of Max-U thinking among economists] think of governance failures as a problem of institutions, and the solution they say, lies in changing the structure of incentives to enhance accountability. True, but these failings also have a moral dimension'. ${ }^{13}$ It is no surprise that an Italian and an Indian make such an anti-institutional point, from countries as corrupt as the United States was in the nineteenth century, and as Illinois and Louisiana still are. They have seen fresh institutions such as the Italian insertion of a level of government between the national and the commune or the Indian regulation in detail of every aspect of economic life fail, miserably.

The economic point against the neo-institutional story of how we got rich can be made with any of the numerous supply-and-demand diagrams that litter elementary texts in economics. ${ }^{14}$ Take, for example, a nation's supply of and demand for labor. Suppose that the opportunity cost of labor is upward-sloping, measuring the value of the next hour of labor in activities alternative to working in, sat, Britain, such as working abroad or taking one's ease. Now add into the diagram the demand curve for British labor, which of course is downward

12 Zamagni (2010), p. 63.

13 Das (2009), p. xxxiii-xxxiv.

14 For detailed justifications for what follows see McCloskey (1985), Chps. 22-25. 
Figure 1. Institutional change of a static sort cannot explain modern economic growth.

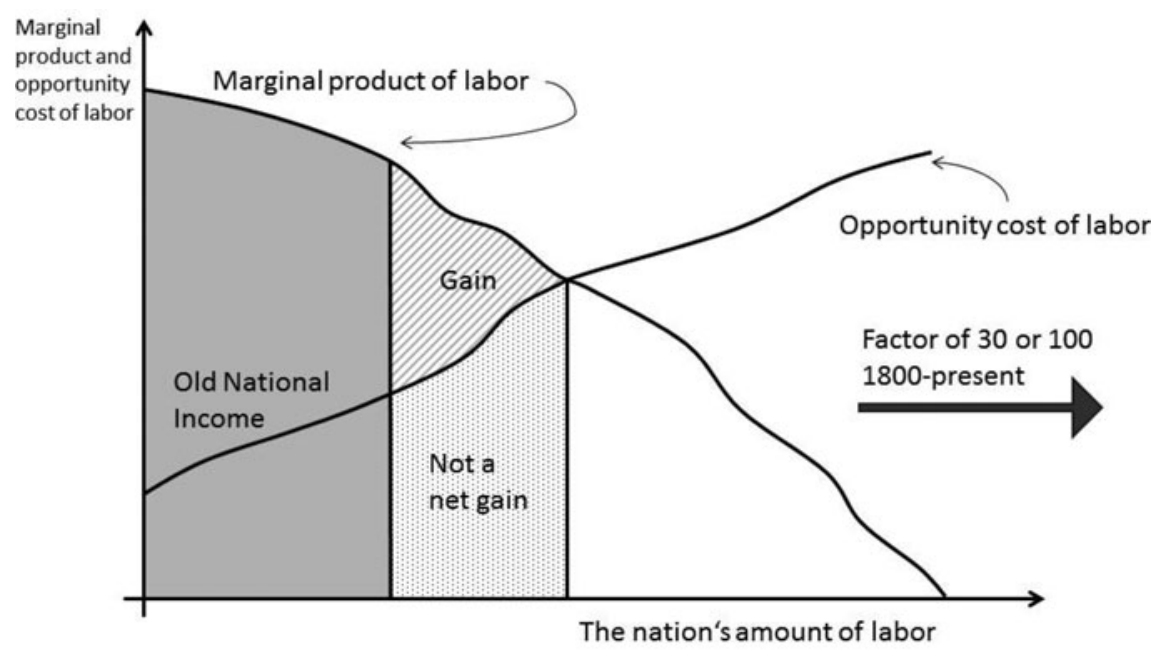

Gains of efficiency are dwarfed by the Great Enrichment 1800-present

sloping because any extra labor gets employed in less urgent employments. Such a marginal product of labor curve, as labeled in Figure 1, is the market value of the product of the last hour demanded.

If there is no misallocation of labor, the nation will be led by market forces to employ labor up to the point at which the two curves cross. At that point, national income will be as large as it can be, considering the existing marginal product and opportunity cost of labor. (To speak more technically, total income obviously is, up to a constant of integration, the integral under the marginal curve - that is to say, the area under the partial derivative curve known to us as the marginal product of labor.)

And it will be good for the society as a whole to be at such a point of efficiency. 'Efficiency', after all, is that the last hour of work gets in goods just what it sacrifices in, say, taking ones ease. It is what you individually want to do in allocating your own hours between labor and leisure. So too the nation. If by misallocation it happens that too little labor is employed, putting the economy at the vertical line to the left, the line of too little labor, there would be a gain foregone of national income, the triangle labeled Gain. (Technical remark: Why does the gain not include the trapezoid below Gain? Because the trapezoid is the value of the opportunity costs of labor - taking ones ease or working abroad of the work not employed at home, and is not a gain to the workers enjoying it. The inefficiency of foregone Gain, by contrast, is a gain to no one.)

A government can impose policies that make quite large the foregone Gain compared to the income at the efficient point. North Korea, for example, is good 
at this. But in the other direction, on any reasonable view of how economies work a government can't by laws hampering free exchange make the marginal product of labor rise, at any rate not by a factor of 100 when allowing for the improved quality of goods and services since 1800 , or even the 20 or 30 as conventionally measured.

And the crucial point is that even laws that reduced the misallocation leading to a loss in the first place would yield gains very small by comparison with pregood-law income. Look at the diagram again, and note the big arrow labeled 'Factor of 30 or 100 1800-present'. It is the big arrow, not the little gains from efficiency, that explain the order of magnitude of real income per person in the modern world. That is, the great bulk of the enrichment of the modern world has not come (as some of the right argue) from repairing technically inefficient institutions, and in any case could hardly come (as some on the left argue) from laws further hampering free exchange.

The point is to show that the static assumptions of neo-institutional economics cannot have the quantitative oomph they claim in explaining the elephant in the room of modern social science (as one referee of the paper perceptively put it), massive modern economic growth. It will not do to reply that a small change, $2 \%$ per year, say, adds up to $100 \%$ (or so) in two centuries. 'Compound interest' is not a reply. It does not tell why the compounding only started in 1688, and in any case a static gain is precisely not compounded. If railways increased national income by two percent, they did it once, not every year. It remains to discover why the society changed to give a dynamic improvement of $2 \%$ every, single year.

Misallocation has limits, in other words, and therefore repairing it has limits, far below the orders of magnitude of the Great Enrichment. It is possible to reduce even a very high income to $\$ 1$-a-day or less if the government goes insane, as governments have with some regularity been doing since they first came into existence. Witness Assad's Syria, or Nero's Rome, or the conquering Mongol's original plan (they soon came to their senses) to turn the rich agricultural fields of China into depopulated grazing grounds for their horses. But suppose bad government and market failure and wretched property rights reduced income originally by as much as $80 \%$ of its potential. In that case, a perfect government correcting all market failures and establishing ideal property rights would increase income by a factor calculated by dividing the gain of 80 divided by the original, miserably inefficient 20, a factor of 4 . Splendid. But the Great Enrichment was a factor not of 4 but of 20 or 30 or 100 .

The repair can have, to be sure, secondary effects of encouraging betterment that does in turn produce enrichment at the astonishing order of magnitude of 1800 to the present. But the neo-institutionalists have no theory for this crucial step, the step of the creative production of novelties - except a theory (exploded by Mokyr's and Boldrin and Levine's recent work) that, say, patents make novelties into routine property and a therefore subject for the routine investment 
beloved of Samuelsonian economists. ${ }^{15}$ Without the new liberty and dignity uniquely enlivening ordinary people in northwestern Europe, the repairing of incentives can't produce much. Most of the enrichment came from the curves in question zooming out by gigantic magnitudes, as a result of spillovers from the whole world's market-tested betterments. That is, what made the modern world was the radically improving of ideas, such as the idea of the electric motor or the idea of the skyscraper or the idea of the research university - not the mere facilitating of property (as conservative economists recommend) or the mere hampering of property (as progressive economists recommend).

A government can do very little by the quantitative standard of the Great Enrichment. If the place starts with the usual rights to property and the usual modest corruptions or robberies, it cannot achieve anything resembling the 1,900 or 2,900 or $9,900 \%$ per person real growth of modern economies 1800 to the present merely by routine efficiency, which is old, or by routine mercantilism, which is also old, or least of all merely by wishing it and issuing propaganda that it has in fact been achieved, which was the old Red-Chinese formula, and a habit of kings claiming credit for a prosperity they did nothing to cause. If even moderately well governed, there has been historically usually nothing like a $99 \%$ idiocracy to recover from merely by allowing people to exercise routine prudence. A country achieves the Great Enrichment by allowing improvers to creatively destroy earlier ways of doing things. If the sultan throws the improver off a cliff, the Ottoman Empire will remain poor, however snappily it equalizes known marginal cost and known marginal valuation.

Bettering institutions of government do not explain the bulk of a modern levels of income. New Zealand, for example, is honestly and efficiently governed. Italy is not. In ease of doing business, New Zealand ranked in 2010 and 2012 (among 183 or 185 countries) third from the top. Italy in 2010 ranked eightieth, slightly below Vietnam, and in 2012 seventy-third, slightly below the Kyrgyz Republic. In 2012, according to the Corruption Perception Index of Transparency International, among 173 ranked countries New Zealand was tied for first, the most honestly governed. Italy was seventy-second. ${ }^{16}$ In 2009 in the Economic Freedom Rankings, New Zealand ranked first in its legal system and fifth from the top in its freedom from regulation. Italy in its legal system ranked sixty-third, just above Iran, and ninety-fourth in its freedom from regulation, just above the Dominican Republic. ${ }^{17}$ Italy, as any sentient Italian can tell you, has terrible public institutions.

Yet in real GDP per person New Zealand and Italy in 2010, were nearly identical, at \$ 88.20 and \$ 86.80 a day, a little above what Hans Rosling calls

15 Boldrin and Levine (2008), Mokyr (2009).

16 http://www.transparency.org/cpi2012/results.

17 World Bank, 'Doing Business', http://www.doingbusiness.org/rankings; real income, Penn Tables for 2010 . 
the Washing Line, at which people start buying washing machines. It is not efficiency as economists think of it that is the best of the good news of the Great Enrichment, but utterly novel betterments causing the marginal product of labor curve to zoom out such as asphalt-paved roads, cheap screws and bolts, sewer traps in plumbing, screens on open windows, widespread secondary schools, computers and the internet - the sort of betterments which can be adopted even by a terribly governed economy, such as Italy's, with satisfactory results.

$* * *$

No institution - not the state or the church or the university or the republics of science and letters - rationally intended the frenetic betterment that has characterized the West and now the rest since 1800. That is another reason why the economist's Max-U neo-institutionalism does not explain what it claims to explain. The economists want to reduce motivation to predictable Max U. But the point is that the modern world was not predictable. It depended on the new and liberal notion of liberty and dignity, and their unpredictable results in betterment for all.

Yet liberty and dignity are not easy to achieve, because they require accepting commercial profit, rejecting tribal protectionism, resisting the temptations of a reasonable sounding 'planning' or 'regulation', and embracing an ideological change towards equality for women and the poor and low-status castes that traditional societies and even some modern societies resist. As French economists reported about slow growth in Madagascar, 'although the Malagasy people lay claim to democratic principles, they remain torn between the demands of democratic and meritocratic nature and the traditional values that impose respect for the real and symbolic hierarchies they have inherited from the past'. ${ }^{18}$ The miracle is that France itself, or for that matter honors-drenched Britain, both heavily regulated, are not instances.

In any case it won't suffice, as the World Bank nowadays recommends, to add institutions and stir. You can set up British-like courts of law, and even provide the barristers with wigs, but if the judges are venal and the barrister have no professional pride and if the public disdains them, then the introduction of such an institution will fail to improve the rule of law. The economist Acemoglu and the political scientist Robinson report on an attempt to curb absenteeism among hospital nurses in India by introducing the institution of time clocks. ${ }^{19}$ The economists in charge of the experiment were sure that the bare incentives of the 'right institutions' would work. They didn't. The nurses conspired with their bosses in the hospitals to continue not showing up for work. Acemoglu and Robinson draw the moral that 'the institutional structure that creates market

18 Razafindrakoto et al. (2013), English abstract.

19 Acemoglu and Robinson (2012), p. 450. 
failures' is what went wrong. But the continuing absenteeism was not about institutions or incentives or market failures. New institutions with the right, unfailing incentives had been confidently applied by the economists out of the tool kit of World-Bank orthodoxy, and went wrong. The wrongness was rather about a lack of an ethic of self-respecting professionalism among the nurses, of a sort that, say, Filipino nurses do have, which is why they are in demand worldwide. The time-clock experiment imagined $P$-only when humans are also motived by $S$.

Acemoglu and Robinson do not see that what failed was the new $P$-only, Max$\mathrm{U}$ theory of the economics profession of add-institutions and stir. 'The root cause of the problem', they conclude, was 'extractive institutions'. On the contrary, the root was ethical failure, in the presence of which no set of instituted incentives will work well, and under which extraction will persist. The institutions - the time clocks and the management practices - and the incentives they are supposed to provide, as though to rats in a maze - were not the problem. The problem was defects in the ethics and in the impartial spectator and in the professionalism of the nurses and their bosses.

The economist Coate shows in his paper on the swift recovery of San Francisco from the earthquake of 1906 that the existing (and corrupt) political institutions of the city were shoved aside. The Army, stationed at the Presidio, and a committee of business and civic leaders - which was also, as was the Army's 73-day-long patrolling of the ruined city, Coate observes, 'extralegal' - took charge. Yet he quotes with approval in his conclusion a remark by the fine if conventionally Samuelsonian economist, Jack Hirschleifer: 'Historical experience suggests that recovery [from a disaster] will hinge upon the ability of government to maintain or restore property rights together with a market system that will support the economic division of labor'. ${ }^{20}$ No: it was the ethics, and the ethos, of the Army and the committee, and nothing like 'the ability of [legitimate] government' that saved the city, just as in 2005 it was private companies springing into action, not any level of government, that partially saved New Orleans during and after Katrina. ${ }^{21}$ In both cases, if existing formal institutions had been relied upon the result would have been further malfeasance by the institutions - such as in New Orleans the malfeasance of the police department and the office of Mayor Ray Nagin.

The ur-neo-institutionalist Williamson, in his reflections on governmental bureaucracies - 'public agency' - calls ethics 'probity', that is, 'the loyalty and rectitude with which the ... transaction is discharged'. ${ }^{22}$ Like all proper Samuelsonian economists, Williamson wants to reduce ethics to incentives: 'probity concerns will be relieved by governance structures to which reliable

20 Coate (2010), p. 15.

21 Chamlee-Wright and Storr, eds. (2010).

22 Williamson (1999). 
responsiveness can be ascribed', by which he means incentives that work to make it unnecessary for anyone actually to have probity. He claims that 'probity concerns' only arise in 'extreme instances'. 'Breach against probity is better described as inexcusable incompetence or even betrayal. In the limit, such breach is punishable as treason'. His is a common error in recent thinking about ethics, supposing that ethics is only about grand issues ('extreme') such as murder or abortion or outright fraudulence in accounting, 'House-of-Cards' instances, one might say. But ethics is also about daily good will and professionalism, such as an accountant doing as well as she can, or a professor trying to tell the truth.

Williamson claims repeatedly, as economists do when adhering to the dogma of de gustibus non disputandum est, that ethics change only very slowly. But there is no historical or experimental evidence for such a claim. Sometimes ethics, a matter of $S$ and parts of $L$, changes quickly. Sometimes it does not. You have to find out. The ethics of market participation by married women, for example, changed swiftly in the U.K. from the 1960s on, partly because of the pill but partly because of an ideological upheaval. The ethics of the Roman state in the late first century BCE did not change from republican to imperial slowly. The ethics of western Christianity in the early sixteenth century did not change from a relaxed régime of indulgences to a rigorous Protestantism of congregational shaming slowly.

And most to the point here, the British ethics evaluating markets and innovation in the late eighteenth century did not change from contempt to admiration slowly. In fact, ethics (understood not as individual ethics but what is honored or dishonored by the society) is what changed in the eighteenth century rapidly, not the institutional environment. A time traveler from England in 1630 or Britain from 1730 would not have been astonished by the institutional arrangements of the United Kingdom in 1830, except for the shift to the transcendent power of a (thoroughly corrupt) Parliament and the weakening of the (thoroughly corrupt) King. The law courts worked as they had ('This is the Court of Chancery', Dickens intoned). Property rights had not changed. Criminal law was still fiercely slanted against the poor. Institutions, such as corporate law, changed after the ethical change, not before.

Ideological change brings a new impartial spectator into the habits of the heart. Institutions are frosting on the cake if they lack ethical backing, from the bus driver taking professional responsibility for the plans and the lives of the sixty people under his care to the politician resisting the well-placed bribe offered by a highway construction firm. New egalitarian ideas in Europe - according to which bus drivers and politicians, professors, and housewives, felt themselves empowered to be equally responsible - broke the cake of custom. Surprisingly, the idea of treating people as free and honorable made us all in Britain, Japan, and the United States by historical standards immensely wealthy - that zooming out of the marginal product of labor. 
The neo-institutionalist economists have not really taken on the idea that ideas can matter independent (sometimes) of incentives. They say they have taken it on, and become cross when some idiot claims they do not. But then they keep falling back into simplified arguments that say that institutions (let's symbolize them by $N$, since the other term, Ideas, also start with an $I$ ) suffice for growth $(G)$

$$
N \rightarrow G
$$

That is, (good) Institutions imply (positive) Growth. The neo-institutionalists in their actual scientific practice are denying what can be shown on the basis of masses of positivist, behaviorist, and Samuelsonian evidence, but also on the basis of the humanistic testimony of plays, novels, philosophy, biography, and ordinary human experience, namely, that (remember $N$ is institutions, $D$ is ideas)

$$
N \text { and } D \rightarrow G \text {. }
$$

The ideas, $D$, are to be thought of as 'sound, pretty favorable ideas about markets and betterment'. Likewise, the Institutions, $N$, are to be thought of as 'not perfect but, John-Mueller style, pretty good'. ${ }^{23}$ What actually changed in the eighteenth century in Britain, for example, was $D$, ideas, pretty much, not institutions.

If one believes with North and Acemoglu and others that, near enough, $N \rightarrow G$, then it follows in strict logic that not $-G \rightarrow$ not $-N$, and the hunt is on for institutions that failed, and kept nations failing. But suppose one believes that $N$ and $D \rightarrow G$, as Donald Boudreaux has persuaded me to admit (tamping down my annoyance at the arrogance of the new orthodoxy in economics), and as Joel Mokyr and John Nye have helped me to see more clearly. ${ }^{24}$ Then it follows in equally strict logic that not- $G \rightarrow$ either not- $N$ (the bad institutions) or not- $D$ (the bad ideas), or both. (The logical point in the philosophy of science is known as Duhem's Dilemma, which, if economists knew anything about the actual philosophy of science, would demolish in two lines of symbolic logic the Friedman-Samuelson falsificationism for simpletons underlying modern econometrics.) If so, then the hunt is on for either bad institutions or bad ideas, with no presumption that hunting for the bad-idea possibility is somehow less of a scientific priority.

I recognize the impulse to stick with Max-U version of institutions as the first on the agenda, since I used to say the same thing to conventional, nonquantitative economic historians like David Landes: 'First, David, let's use measures of total factor productivity; then, if there's anything left over, we

23 Mueller (1999).

24 Hart and Richman, eds. (2014). 
can look into the archives of the correspondence of ironmasters'. I never intended to look at the archives, and did not in fact do so, to my shame. Samuelsonian economics, I thought, sufficed. So here. (To the claim that Northian institutionalism steps beyond Samuelsonian economics, by the way, I say again, as I have been saying to the good Douglass now for thirty years, I think not: neo-institutionalism is Samuelsonian economics in evening dress.)

Consider an institution that undoubtedly did encourage growth, namely, a large free-trade area in which local interest could not block entry. It was expressed in black-letter law in the American Constitution, and in practical terms was prevalent in Britain (though not until the 1780s instituted also in John Bull's other island). Customs unions like the Zollverein or the Austro-Hungarian Empire were other examples of a big free-trade area. So was the Chinese Empire.

Local monopolies able to prevent entry, as in European guilds, surely did discourage growth, which is to say not- $N \rightarrow$ not- $G$, from which one might want to deduce that $\mathrm{G} \rightarrow \mathrm{N}$, that is, that if there was growth there must have been the institutions of large free-trade areas. But the trouble is that even with a large free-trade area in black-letter law, an irritating competition from across the mountains might inspire people to petition the state for protection. In fact, it does. Without a strong ethical conviction, $D$, such as the conviction that spread widely in Britain and Ireland in the nineteenth century that such petitioning is bad or shameful, the black letters will be dead. $N$ and $D \rightarrow G$. Ideas matter, ideology matters, ethics matter.

It is not reasonable to reply that North and Greif and the rest do admit the force of ideas in their neo-institutionalist stories. In his Understanding the Process of Economic Change (2005), for example, North says repeatedly that he is interested in the source of ideas. Good. But instead of entering the humanistic conversation since cuneiform on clay, which has largely been about the source of ideas, he defers to the 'brain sciences' (about which it must be said North knows very little). That is, he reduces ideas to matter, and to the mechanical incentives surrounding matter, every time. He takes the brain to be the same thing as the mind, which after all is the central error in the phrenological branch of the brain sciences.

The less dogmatic of the neo-institutionalists, such as Joel Mokyr and John Nye, seem on odd days of the month to believe in the North-Acemoglu prejudgment that $N \rightarrow G$. No ideas present. On even days the lesser-dogmatists calls ideas, $D$, 'culture', which is the vague way people talk when they have not taken on board the exact and gigantic literature about ideas, rhetoric, ideology, ceremonies, metaphors, stories, and the like since the Greeks or the Talmudists or the Sanskrit grammarians.

A referee pointed out to me what I should have seen originally: that my argument for the importance of ideas, $D$, might have had the merely static effects I deprecated earlier here. That's right. But the historical point is that the ideas changed. The institutions did not. It is quite wrong to think that the institutions 
faced by British entrepreneurs in 1800 were radically different from the ones they faced in 1685. But ideas of what was honorable, appropriate, allowed among right-thinking folk did change, radically. And the economic point is that ideas are intrinsically subject to economies of scale ('ideas having sex', says Matt Ridley), but institutions are often as not deeply conservative. To believe all this you will have to read and love Bourgeois Equality: How Betterment Became Ethical, 1600-1848, and Then Suspect, forthcoming from the University of Chicago Press in 2016. In that fine work I provide some reason, at least, to believe that the change in ideas was dynamic in the technical sense, whereas the change in institutions was mostly not. Or at least (says Horatio in Hamlet 1,1,142), 'So I have heard, and do in part believe in'.

Let me exhibit what can be learned from the actual humanities and the actual brain sciences, the serious study of $D$, tending even to a dynamic conclusion. We humans have an unusual capacity. Creativity among humans is performed by what the philosopher Searle has called a 'status function', that is, a purpose performed by a person (such as a president) or a thing (such as a $\$ 20$ bill) or an entity (such as a limited liability corporation) by virtue of a social agreement. Searle formulates it as ' $X$ is treated as $Y$ in the context $C$ '. The crossing of the goal line by the ball is treated as a goal (one point) in the context of playing soccer.

Searle insists that any status function requires language. 'Without a language', he writes, 'you have only pre-linguistic intentional states such as desires and beliefs together with dispositions'. ${ }^{25}$ These pre-linguistic functions are what economists call utility functions and constraints. Economics after Adam Smith has been determinedly pre-linguistic. In Marx or in Samuelson language and its accompanying ethical valences expressed in language don't matter. What matters are desires and dispositions combined with powers (and Searle observes that the very powers come from speech, too). 'To get to the point that you can recognize an obligation as an obligation', Searle points out, 'you have to have the concept of an obligation, because you have to be able to represent something as an obligation, that is, something that gives you a reason for action independent of your inclinations and desires'. ${ }^{26}$ Notice the words 'recognize', 'concept', 'represent'. They play no part in economics understood as not needing language. Game theory in economics is precisely the claim that we can do without language and language-created meanings. Shut up and play the game, consulting your budget constraints and your preferences. Searle and I and many brain scientists disagree with such a reduction: 'Games and other nonlinguistic institutional phenomena can be explained only in terms of language. You can't

25 Searle (2010), p. 95.

26 Searle (2010), p. 96. 
use the analogy with games to explain language because you understand games only if you already understand language'. ${ }^{27}$

Treating $X$ as $Y$ in the context $C$ looks trivial, merely a figure of speech, mere talk. So it is, Searle argues, if it is merely a 'linguistic institutional fact', such as 'all unmarried men are bachelors'. Treat a man as something called a bachelor under the circumstances that he is unmarried and you are speaking English. But treating $X$ as $Y$ under circumstances $C$ becomes a 'nonlinguistic institutional fact', with consequences ('powers') beyond mere language when the circumstances and the person doing the treating have extra-linguistic powers arising from agreed conventions (themselves arising from language). Language establishes the meaning of the word 'bachelor', but the extra-linguistic context creates the powerful consequences: that Bachelor $X$ can marry a woman (and under the U. S. Protection of Marriage Act, only a woman).

Meaning is the only power inside language itself. If I promise to review a book the speech act of promising means ... well ... I hereby promise to review the book. Don't count on it. But if the extra-linguistic context obtains that the editor is a dear friend of mine, the promise plus the context creates a power beyond meaning. It gives me a reason for action independent of my inclinations and desires to, say, work rather on my own book, or watch a cricket game. 'Once you have a common language, you already have a society', declares Searle. True. And therefore as the language changes, so changes the sort of society one can have. The language game, as Wittgenstein put it, determines a form of life. As the English word 'honest' shifted from an aristocratic to a bourgeois sense of honor the sort of deals we could make, the sort of action we could countenance, changed. To call a man 'dishonest' in an aristocratic society requires a duel with swords next morning. To call a man 'dishonest' in a bourgeois society requires a suit for libel. ${ }^{28}$

Economic innovation 'counts as' (to use Searle's vocabulary) honorable only in the Bourgeois Era. Or to be exact, what was honorable ('honest') in the Aristocratic Era was innovation without a market test. No one asked if a new machine of war was profitable. The clerisy, those pseudo-neo-aristocrats of 'merit', judge their merit in non-market terms. The well-named honorary degrees count for more than high pay. I witnessed a discussion of a candidate for an academic job in which his success with a popular book in addition to his large and fine scholarly output was offered as a reason not to hire him. Profit makes a neo-pseudo-aristocrat dirty, at any rate if she cannot well conceal the dirt.

But Searle's analysis needs another word, which one might coin as 'conjective', what we know together as against what we know inside an individual head or what we imagine to be God's objectivity. The conjective is a result of human

27 Searle (2010), p. 115.

28 For (much) more on 'honest' (and eerlich) see McCloskey (2015). 
agreement or acceptance. The Latin is cum + iactus, that is, 'thrown together', as after all we humans are in our mammalian cuddling and especially in our conversations.

'Institutional facts are typically objective facts', Searle writes, by which he means that they bite. That a $\$ 20$ bill, to take his favorite example, buys $\$ 20$ worth of clobber bites as deeply in our lives as does the physical fact that the bill falls to the ground if you let go of it. (And after it falls what does mere physics - 'brute facts' in Searle's way of talking - imply about its future location? A mistaken prediction. Economics predicts that someone will pick it up, which is not something one could learn from its brute-fact, physical equilibrium on the floor.) He continues: 'oddly enough, [the institutional facts] are only facts by human agreement or acceptance'.

But there's nothing odd about it. Tallis, himself a distinguished neuroscientist, reviewed favorably Who's in Charge?: Free Will and the Science of the Brain by Gazzaniga, whom he describes as 'a towering figure in contemporary neurobiology'. Tallis writes, sprinkling in phrases from Gazzaniga, 'Crucially, the true locus of this activity is not in the isolated brain'

but 'in the group interactions of many brains', which is why 'analyzing single brains in isolation cannot illuminate the capacity of responsibility' [consider the contrast with the procedures in behavioral economics and some experimental economics]. This, the community of minds, is where our human consciousness is to be found, woven out of the innumerable interactions that our brains make possible. 'Responsibility' (or lack of it), Mr. Gazzaniga says, 'is not located in the brain'. It is 'an interaction between people, a social contract'-an emergent phenomenon, irreducible to brain activity'.

The American historian Thomas Haskell wrote in 1999 a startling essay chronicling the new prominence of 'responsibility' in a commercial America in the eighteenth and nineteenth centuries. The Oxford English Dictionary gives 1787 as the earliest quotation of 'responsibility' in its modern sense as accepting that one has done such-and-such, by Hamilton in The Federalist Papers, and shortly thereafter by Edmund Burke. Haskell notes that it is used much earlier in law in the sense of being required to respond to a legal action. Such a 'responsible' person, meaning 'liable to be called to [legal] account' (sense 3a), occurs as early as 1643 . The OED's earliest quotation for the favorable ethical meaning, the dominant modern sense, 'morally accountable for one's actions; capable of rational conduct' (sense $3 \mathrm{~b}$ ), is as late as 1836 - which is Haskell's point. The linking of 'responsibility' with the market like word 'accountability' occurs in the very first instance of 'accountability' detected by Haskell, in 1794 in Samuel Williams' Natural and Civil History of Vermont, 'No mutual checks and balances, accountability, and responsibility' (the older noun is 'accountableness', dating from 1668; the adjective 'accountable', 1583; and simple 'account' or 'accompt', are medieval). 
Haskell is wary of praising the new dignity for market participants: 'my assumption is not that the market elevates morality'. But then he takes it back: 'the form of life fostered by the market may entail the heightened sense of agency'. ${ }^{29}$ Just so. Surely commerce, with seventeenth-century religion and church governance, among the radicals heightened the sense of individual, responsible agency. Earlier in the essay Haskell had attributed to markets the 'escalating' sense of agency, 'responsibility'. So the market did elevate morality. So much we can learn from humanistic historians studying the very words.

To return to what can be learned from actual brain scientists, Tallis concludes, in his own eloquent words (he is a published poet, too): 'we belong to a boundless, infinitely elaborated community of minds'

that has been forged out of a trillion cognitive handshakes over hundreds of thousands of years. This community is the theater of our daily existence. It separates life in the jungle from life in the office, and because it is a community of minds, it cannot be inspected by looking at the activity of the solitary brain.

Human agreement or acceptance, what the philosopher Michael Oakeshott called the conversation of mankind, is precisely what I call the conjective, as against merely subjective.

Searle argues persuasively that a society is glued together by conjective facts of the sort ' $X$ counts as $Y$ in context $C$ '. Thus, a clergyman saying 'I thee wed' counts as marrying two people in the context of a properly constituted marriage ceremony. A \$ 20 bill counts as legal tender in the context of the territories of the United States. A ball going over the goal line counts as a goal in the context of a soccer game. As Fish so often notes, of course, such conjective facts are always contestable. Objective facts ('water is two molecules of hydrogen and one of oxygen') or subjective facts ('Beckham intends to score a goal') are not. The physical facts of the world and the psychological states of human minds are 'brute', to extend Searle's word, in the sense of being incontestable in their very nature, their 'ontology' as the philosophers say. Physical constraints such as the law of gravity and utility such as a great love for vanilla ice cream are not the sort of facts we can quarrel about once we have grasped in a humanistic inquiry their nature, their 'qualia', as the philosophers put is. All we can do then is measure, if we can.

The conjective by contrast is always contestable and always in that sense ethical, that is, about 'deontic status', in Searle's vocabulary, 'deontic' being about what we ought to do (the Greek means 'being needful'). The clergyman might be argued to be not properly authorized to perform the marriage (look at the long controversy about gay marriage), the definition of 'U.S. territory' might be ambiguous (embassies abroad?), the goal might be disputed. If any part of the

29 Haskell (1999), p. 10. 
ball breaks the plane of the goal line is it a goal? Was the linesman in a position to judge?

The theologian Martin Buber wrote in 1909 that 'there is no "I" taken in itself', that is, no solipsism, beloved of the dogmatic methodological individualist. As the economist Wilson points out, and has shown in linguistic analysis and laboratory experiments, such a thing as 'social preference' resides in our language games amongst ourselves, not within our isolated utility functions. 'The fundamental fact of human existence', Buber wrote in Between Man and Man 'is neither the individual as such nor the aggregate as such, but "man with man"'. It is neither subjective nor objective ('Objective truth is not granted to mortals', said Buber at the treason trial of Aharon Cohen in 1958, not perhaps the best thing to have said under the circumstances). It is, one may say, 'conjective', the 'between' in Buberian talk, what we know in speech and meetings and dialogue, one human with another.

What Searle does not appear to understand, though, is that his formulation of a status function - ' $X$ is treated as $Y$ in the context $C$ ' - is itself analyzable into a metaphor ('Treat the female child Jannike as Mommy') and a story ('We are playing house': once upon a time there was a house with a Mommy and a Daddy; and so the story continues as we play with exciting events characteristic of families). In a word, Searle's status function is an allegory, and literary methods are to be brought into the analysis of institutions. Pilgrim's Progress is an allegory of the metaphor of a spiritual life as a journey ('Treat a literal journey as a metaphor of spiritual challenge and development') with a story giving the metaphor a dimension of metonymy through time (events in a story are contiguous to each other, not like each other). It's like playing house. Searle correctly noted that human children 'very early on acquire a capacity to do this double level of thinking that is characteristic of the creation and maintenance of institutional reality. Small children can say to each other, "Okay, I'll be Adam, you be Eve, and we'll let this block be the apple"'. Tomasello and colleagues have shown in ape-human experiments that 'human thinking [that is, the function of the very brain itself, the 'preference ordering' in the economist's jargon] is fundamentally cooperative'. Human infants, for example, unlike their close cousins among the great apes, point. That is, they "form a "we" that acts as a kind of plural agent' (Tomasello indeed cites Searle in this connection). And children evaluate, engaging in 'objective-reflective normative thinking', ethics in a real world of brute facts and human intentions.

So what? Well, let's get serious about 'brain science' and let's acknowledge that the humanities, and the higher culture generally, can shed light on 'institutions'.

Searle is satisfied with calling allegory-making 'an element of imagination' and 'fantasy', without bringing to bear the research from ancient times to the present on human abilities to form metaphors and metonymies. He says that 'creating institutional facts' such as that professors, not the students, lead classes or that walkers stay to the right on a crowded sidewalk or that Elizabeth II is the 
queen of England depends on 'one formal linguistic mechanism'. The institutional facts 'carry deontic powers', that is, they 'provide us with reasons for acting that are independent of our inclinations and desires', such as the (recognized) responsibility of the professor to lead the class or the (acknowledged) right to not be bumped into on a crowded sidewalk or the (accepted) power of Elizabeth to exercise her advisory role. The institutionalist economists call them constraints or the rules of the game. Searle notes, citing his understanding of Durkheim, that 'Some social theorists have seen institutional facts as essentially constraining. That is a very big mistake'. Whether Durkheim committed the mistake is not so clear. But North and associates certainly do commit it. Institutions, Searle is arguing, are not about regulating relations between pre-existing people and objects. They are about creating entirely new power relationships between people, and then continually negotiating about them. That is what is magical about status functions. We declare our independence and thus fashion a new relationship of power between King George and his former subjects.

In other words, it's more complicated than mere budget constraints between buying ice cream and paying the rent. Searle points out that there are two kinds of rules, regulative ('Don't steal'; 'Drive on the right'), which apply to already existing activities, and constitutive rules, which create the very activity ('Follow these rules and you are playing chess'; 'Act is this way and you are being a proper bourgeois'). It is language, in particular the combined metaphors and stories we use to create allegories called institutions. If the science of economics, as the economists Nona and Storr argue, needs meaning - it needs, deontically, not merely rules of the game or brain science but the humanities all the way up to the department of English. ${ }^{30}$

\section{$* * *$}

Another example. North speaks highly of the anthropologist Geertz. It is hard not to. North reads Geertz and his coauthors, though, as supporting the economistic notion that in caravan trade, such as in Morocco around 1900, in North's formulation, 'informal constraints [on, say, robbing the next caravan to pass by] ... made trade possible in a world where protection was essential and no organized state existed'. North misses the non-instrumental, shame-andhonor, non-Max-U language in which Geertz in fact specialized, and misses therefore the dance between internal motives and external impediments to action, between the dignity of a self-shaping citizen-not-a-slave and the merely utilitarian 'constraints'. The toll for safe passage in the deserts of Morocco, Geertz and his coauthors actually wrote, in explicit rejection of Max U, was 'rather more than a mere payment', that is, a mere monetary constraint, a budget line, a fence, an incentive, an 'institution' in the reduced definition of Samuelsonian economics.

30 Nona and Storr (2012). 
'It was part of a whole complex', the anthropologists actually wrote, 'of moral rituals, customs with the force of law and the weight of sanctity'. ${ }^{31}$

'Sanctity' doesn't mean anything to North the economist, who for example in his book treats religion with an unlettered contempt worthy of Richard Dawkins or Christopher Hitchens ('Ditchkins', says Eagleton). Religion to North means just another 'institution' in his utilitarian, subject-to-constraints sense, that is, rules for an asylum. He labels religion repeatedly 'nonrational'. Religion to him is not about sanctity or the transcendent, not about faithful identity, not about giving lives a meaning through moral rituals. It is certainly not an ongoing intellectual and rational conversation about God's love, not to speak of an ongoing conversation with God. Religion is just another set of constraints on doing business, whether the business is in the market or in the temple or in the desert. In this North agrees with the astonishing economist Iannaccone and his followers when they come to study religion. Religion to them is a social club, with costs and benefits, not an identity or a conversation. (Anyone who has actually belonged to a social club, of course, knows that it soon develops into 'moral rituals, customs with the force of law, and the weight of sanctity'. I could instance as such a club the Chicago School of economics during its great days in the 1970s. One of our sanctified rituals was to repeat De gustibus non est disputandum, while passionately advocating a very particular intellectual gustus.) North asserts, for example, that in a prelegal stage 'religious precepts ... imposed standards of conduct on the [business] players'. He spurns the worldview that goes with religious faith. (His own religion of Science, of course, is in fact nothing like a mere constraint. He construes it as his identity, his moral ritual, his sanctity - in short, the meaning of his life, negotiated continuously over its extraordinary course. But ethical consistency is not a strong point of Samuelsonian economics.)

Greif, North's ally in neo-institutionalism, calls culture 'informal institutions', and North tries to talk this way as well. ${ }^{32}$ The 'informality', however, would make such 'institutions' very different from asylum-type 'rules of the game'. One does not negotiate the rules of chess. But informality is continuously negotiated - that is what the word 'informality' means, exactly the degree of setting aside rules that distinguishes a backyard barbecue from a state dinner. How to behave at the barbecue? (Hint: do not jump naked into the bushes.) Just how far can a man go in teasing his mates? Just how intimate can a woman be with her girlfriends? The rules are constructed and reconstructed on the spot, which in such cases makes the Samuelsonian metaphor of constraints inapt. One does not have to deny that an ethical persuasion is often influenced by incentives to believe that once it becomes part of a person's identity it has an effect independent of the very incentives. Once someone is corrupted by life in a communist country, for

31 Geertz et al. (1979), p. 137; quoted in North 1991, p. 104, italics supplied.

32 Greif (2006). 
example, it is hard to reset her ethics. She goes on relying on the 'bureau' model of human interaction as against the market. Once you are educated in Samuelsonian economics, it is hard to reset your intellectual life. You go on thinking of every social situation in terms of Max U's mechanical reaction instead of a socially constructed dance. But the Geertzian metaphor of negotiation and ritual often makes more sense. 'O body swayed to music, o brightening glance, / How can we know the dancer from the dance?'

Some economists grasp that institutions have to do with human meaning, not merely Northian 'constraints'. The Austrians and the old institutionalists managed to escape, Houdini-like, from the straightjacket that North, Becker, Deepak Lal, Greif, Levitt, Max U, and their friends have so eagerly donned. The Austrian economist Lachmann (1906-1990), for example, spoke of 'certain superindividual schemes of thought, namely, institutions, to which schemes of thought of the first order [notice that to the Austrians the economy is in fact thought, all the way down], the plans, must be oriented, and which serve therefore, to some extent, the coordination of individual plans'. ${ }^{33}$ Thus a language is a scheme of thought, backed by social approval and conversational implicatures. Thus too is a courtroom of the common law a scheme of thought, backed by bailiffs and law books.

North, like the numerous other economists such as Levitt who have settled into the straightjacket, talks a good deal about meaning-free incentives, because that is what Samuelsonian economics can deal with. The constraints. The budget lines. The relative price. Yet one can agree that when the price of crime goes up (that is, the incentives change in the direction of, say, harsher punishment) less of it will be supplied, sometimes, yet nonetheless affirm that crime is more than a passionless business proposition. If you don't believe it, tune into one of the numerous prison reality shows, and watch the inmates struggling with the guards, with a mad purpose though prudent means; or listen to Ishmael on Captain Ahab: 'in his heart, Ahab had some glimpse of this, namely: all my means are sane, my motive and my object mad'. ${ }^{34}$ If crime is more than utterly passionless calculations by Max $U$, then changing the ethics of criminals and their acquaintances can affect it - ethics that do change, sometimes quickly. Crime rates fall dramatically during a big war, for example, at any rate on the home front. The metaphors of crime as being like employment as a taxi driver, or of a marriage as being like a trade between husband and wife, or of children being like consumer durables such as refrigerators have been useful. Neat stuff. But they don't do the whole job. Sometimes they are disastrously misleading, as when economists provided ammunition for conservative politicians in the 1990s for increasing punishments for crimes, such as the crime of sitting peacefully smoking a joint.

33 Lachmann (1977).

34 Melville, Moby Dick, Chp. 41. 
Prudence is a virtue. It is a virtue characteristic of a human seeking purely monetary profit - but also of a rat seeking cheese and of a blade of grass seeking light. Consider that temperance and courage and love and justice and hope and faith are also virtues, and that they are the ones defining of humans. Unlike prudence, which characterizes every form of life and quasi-life down to bacteria and viruses, the non-prudential virtues are uniquely characteristic of humans, and of human languages and meanings. In no sense is a prudent blade of grass 'courageous', or a prudent rat 'faithful' (outside of the movie Ratatouille, whose humor turns on the irony of the rat hero being more faithful, and less motivated by prudence only, than many of the humans). As Hugo de Groot, in Latin 'Grotius', put it in 1625, 'The saying that every creature is led by nature to seek its own private advantage, expressed thus universally, must not be granted. ... [The human animal] has received from nature a peculiar instrument, that is, the use of speech; I say that he has besides that a faculty of knowing and acting according to some general principles [called 'virtues']; so that what relates to this faculty is not common to all animals, but properly and peculiarly agrees to mankind'. ${ }^{35}$ North and company, however, will have none of human speech and meanings and acting according to some general principle aside from one's own private interest. The positivistic talk about 'constraints' and 'rules of the game' misses what he could have learned from Geertz, Weber, Smith, Aquinas, Cicero, Confucius, Moses, or his mother (North's mother, or Moses's) - that social rules expressed in human languages have human meanings. They are instruments as well as constraints, as Lachmann says, playthings as well as fences, communities as much as asylum rules.

Take for example so trivial an institution for providing incentives as a traffic light. When it turns red it surely does create incentives to stop. For one thing, the rule is self-enforcing, because the cross traffic has the green. (In the old joke a New York city taxi driver drives at high speed through every red light but screeches to a halt at every green. His terrified passenger demands to know why. 'Today my brother is driving, too, and he always goes through red lights!') For another, the police may be watching, or the automatic camera may capture your license plate. The red light is a fence, a constraint, a rule of the game, or of the asylum. So far goes North, and with him most economists.

Yet the red light has meaning to humans, who are more than rats in a prudenceonly experiment facing food incentives. Among other things it means state dominance over drivers. It signals the presence of civilization, and the legitimacy granted to the state that a civilization entails. (Test: you are struggling through a pathless jungle and come upon ... a traffic light: 'Mr. Civilization, I presume'.) It signals, too, the rise of mechanical means of regulation, in contrast to a human traffic officer on a raised stand with white gloves. The red light is in Lachmann's terms a system of thought. It is a system that some drivers find comforting

35 Grotius (1625), propositions vi and vii. 
and others find irritating, depending on their attitudes toward the state, toward mechanical inventions, toward traffic officers. For a responsible citizen, or an Iowan, or indeed a fascist conformist, the red light means the keeping of rules. She will wait for the green even at 3:00 a.m. at an intersection obviously clear in all directions, an intersection lacking a license-plate camera or police person in attendance, or a reliably irresponsible brother on the road, even when she's in a bit of a hurry. Incentives be damned. But for a principled social rebel, or a Bostonian, or indeed a sociopath, the red light is a challenge to his autonomy, a state-sponsored insult. Again, incentives be damned. If the broken-window policy is applied too vigorously it could well evoke an angry reaction from potential criminals, and could result in more, not less, crime, or at any rate widespread resentment of the police. The over-policing in Ferguson, Missouri in 2014 is a case in point.

Meaning matters. A cyclist in Chicago writing to the newspaper in 2008 about a fellow cyclist killed when he ran a red light declared that 'when the traffic light changes color, the streets of our cities become an every-man-for-himself, anything-goes killing zone, where anyone who dares enter will be caught in a stream of intentionally more-deadly, high-mass projectiles, controlled by operators who are given a license to kill when the light turns green'. ${ }^{36}$ The motorist who unintentionally hit the cyclist probably gave a different meaning to the event. A good deal of life and politics and exchange takes place in the damning of incentives and the assertion of meaning - the mother's love or the politician's integrity or the economist's enthusiasm, what Keynes (and after him Akerlof and Shiller) called animal spirits and what Sen calls commitment and what I call virtues and corresponding vices other than prudence only.

Meaning matters, metaphors matter, stories matter, identity matters, ethics matter. Considering that we are humans, not grass, it matters a great deal.

\section{References}

Acemoglu, D. and J. A. Robinson (2012), Why Nations Fail: The Origins of Power, Prosperity, and Poverty, New York: Crown Business.

Adams, J. (1994), 'Economy as Instituted Process: Change, Transformation, and Progress', Journal of Economic Issues, 28: 331-355.

Akerlof, G. and R. Shiller (2009), Animal Spirits: How Human Psychology Drives the Economy, and Why It Matters for Global Capitalism, Princeton: Princeton University Press.

Becker, G. and G. Stigler (1977), 'De Gustibus Non Est Disputandum', American Economic Review, 67: 76-90.

Boldrin, M. and D. K. Levine (2008), Against Intellectual Monopoly, Cambridge: Cambridge University Press.

Carlos, A. M. and F. D. Lewis (1999), 'Property Rights, Competition, and Depletion in the Eighteenth-century Canadian Fur Trade: The Role of the European Market', Canadian Journal of Economics Revue Canadienne d'Economique, 32: 705-728.

36 Aaron Keuhn, letter to the editor, Chicago Tribune, March 7, (2008), p. 20. 
Chamlee-Wright, E. and V. H. Storr (eds.) (2010), The Political Economy of Hurricane Katrina and Community Rebound, Cheltenham, UK: Edward Elgar.

Coase, R. and N. Wang (2013), How China Became Capitalist, Basingstoke, UK: PalgraveMacmillan.

Coate, D. (2010), 'Disaster and Recovery: The Public and Private Sectors in the Aftermath of the 1906 Earthquake in San Francisco', Rutgers University, Newark, New Jersey Working Paper.

Das, G. (2009), The Difficulty of Being Good: On the Subtle Art of Dharma, Oxford: Oxford University Press.

Davis, J. (2012), Medieval Market Morality: Life, Law and Ethics in the English Marketplace, 1200-1500, Cambridge. Cambridge University Press.

Eagleton, T. (2006), 'Lunging, Flailing, Mispunching: Review of Dawkins, The God Delusion', London Review of Books, October 19, pp. 32-34.

Fish, S. (1980), Is There a Text in This Class? The Authority of Interpretive Communities, Cambridge: Harvard University Press.

Fish, S. (2001), How Milton Works, Cambridge: Harvard University Press.

Fouquet, R. and P. J. G. Pearson (2011), 'The Long Run Demand for Lighting: Elasticities and Rebound Effects in Different Phases of Economic Development', Basque Centre for Climate Change (BC3), Working Paper No. 6.

Gazzaniga, M. S. (2011), Who's in Charge?: Free Will and the Science of the Brain, New York: Harper-Collins.

Geertz, C., H. Geertz and L. Rosen (1979), Meaning and Order in Moroccan Society, New York: Cambridge University Press.

Greif, A. (2006), Institutions and the Path to the Modern Economy: Lessons from Medieval Trade, Cambridge: Cambridge University Press.

Grotius (Hugo de Groot) (1625), 'Preliminary Discourse concerning the Certainty of Rights in General', in De iure belli ac pacis. English trans. of 1738, from the French of Jean Barbeyrac, 1720. At Online Library of Liberty, http://oll.libertyfund.org.

Gwartney, J., R. Lawson and J. Hall (2011), Economic Freedom of the World: 2011 Annual Report, Vancouver: Fraser Institute.

Hardin, G. (1968), 'The Tragedy of the Commons', Science, 162: 1243-1248.

Hart, D. M. and S. Richman (eds.) (2014), Discussion with Joel Mokyr, John Nye, and McCloskey of 'Donald J. Boudreaux's "Deirdre McCloskey and Economist's Idea about Ideas" ', Liberty Matters website, July. Indianapolis, IN: Liberty Fund. At http://oll.libertyfund.org/pages/mccloskey***conversation1.

Haskell, T. L. (1999), 'Responsibility, Convention, and the Role of Ideas in History', in P. A. Coclanis and S. Bruchey (eds.), Ideas, Ideologies, and Social Movements: The United States Experience since 1800, Columbia: University of South Carolina Press, pp. 1-27.

Hiser, R. F. (2003), 'Moral Consequences of Institutional Structure', Planning and Markets, 6(1) At http://www-pam.usc.edu/.

Iannaccone, L. (1998), 'Introduction to the Economics of Religion', Journal of Economic Literature, 36(3): 1465-1495.

Kelling, G. L. and J. Q. Wilson (1982), 'Broken Windows: The Police and Neighborhood Safety', The Atlantic, 249: 29-38.

Lachmann, L. (1977), Capital, Expectations and the Market Process, Kansas City: Sheed Andrews and McMeel.

Maddison, A. (2007), Contours of the World Economy, 1-2030 AD, Oxford: Oxford University Press. 
McCloskey, D. N. (1985), The Applied Theory of Price, New York: Macmillan.

McCloskey, D. N. (1998), 'Bourgeois Virtue and the History of P and S', Journal of Economic History, 58: 297-317.

McCloskey, D. N. (2001), 'Women's Work in the Market, 1900-2000', in I. ZweinigerBargielowska, (ed.), Women in Twentieth Century Britain: Economic, Social and Cultural Change, London: Longman/Pearson Education.

McCloskey, D. N. (2008), 'Not by P Alone: A Virtuous Economy', Review of Political Economy, 20: 181-197.

McCloskey, D. N. (2010), Bourgeois Dignity: Why Economics Can't Explain the Modern World, Chicago: University of Chicago Press.

McCloskey, D. N. (2015) (forthcoming), Bourgeois Equality: How Betterment Became Ethical, 1600-1848, and Then Suspect, Chicago, IL: University of Chicago Press.

Mokyr, J. (2009), 'Intellectual Property Rights, the Industrial Revolution, and the Beginnings of Modern Economic Growth', American Economic Review, 99(2): 349355.

Mokyr, J. (2010), 'Culture, Institutions, and Modern Growth', Conference on Understanding Institutions and Development Economics: The Legacy and Work of Douglass C. North, St. Louis, 4-6 Nov, 2010.

Mueller, J. (1999), Capitalism, Democracy, and Ralph's Pretty Good Grocery, Princeton: Princeton University Press.

Nona, M. P. and V. H. Storr (2012), 'Talk Changes Things: The Implications of McCloskeys Bourgeois Dignity for Historical Inquiry', Journal of Behavioral and Experimental Economics, 41: 787-791.

Nodharus, W. D. (1996), 'Do Real Output and Real Wage Measures Capture Reality? The History of Lighting Suggests Not. in T. F. Breshnahan and R. Gordon (eds.), The Economics of New Goods, Chicago: Chicago University Press.

North, D. C. (1991), 'Institutions', Journal of Economic Perspectives, 5(1): 97-112.

North, D. C. (2005), Understanding the Process of Economic Change, Princeton: Princeton University Press.

Parks, T. (2013), Italian Ways: On and Off the Rails from Milan to Palermo, New York and London: Norton.

Razafindrakoto, M., F. Roubaud and J.-M. Wachsberger (2013), 'Institutions, Gouvernance et Croissance de Long Terme à Madagascar: L'énigme et le Paradoxe', Unpublished essay, Université Paris-Dauphine, UMR DIAL (Developpement Institutions \& Mondialisation).

Rossi, G. and S. Spagano (2014), 'From Custom to Law - Hayek Revisited', Unpublished essay Edinburgh School of Law and Department of Economics and business, University of Catania. At http://mpra.ub.uni-muenchen.de/56643/.

Searle, J. R. (2010), Making the Social World: The Structure of Human Civilization, Oxford: Oxford University Press.

Sen, A. (1977), 'Rational Fools: A Critique of the Behavioral Foundations of Economic Theory', Philosophy \& Public Affairs, 6: 317-344.

Tallis, R. (2011), 'Review of Deacon and Gazzanga', Wall Street Journal November 12.

Tomasello, M. (2014), A Natural History of Human Thinking, Cambridge: Harvard University Press.

Williamson, O. (1999), 'Public and Private Bureaucracies; A Transaction Cost Economics Perspective', Journal of Law, Economics and Organization, 15: 306-342. 
Wilson, B. J. (2010), 'Social Preferences Aren't Preferences', Journal of Economic Behavior \& Organization, 73: 77-82.

Zamagni, S. (2010), 'Catholic Social Thought, Civil Economy, and the Spirit of Capitalism', in D. K. Finn (ed.), The True Wealth of Nations: Catholic Social Thought and Economic Life. Oxford: Oxford University Press, pp. 63-93. 